\title{
A magyar hírszerző és elhárító szervek története 1918-tól a II. világháború végéig
}

\section{The History of Hungarian Intelligence and Counterintelligence Agencies from 1918 until the End of World War II.}

A hírszerzés és az elhárítás szerves részei a biztonságért felelös szervezetek mindenkori tevékenységének. Akár politikáról, háborúról, gazdaságról vagy bünüldözésröl van szó, az arra hivatottak igyekeznek minél többet megtudni vagy megörizni ezek titkaiból. A politikai hatalom, a társadalmi viszonyok és a környezö világ változásai erőteljes hatással vannak az erre hivatott szervezetek átalakulásaira és munkájára. A tanulmány a hazai hírszerzés és elhárítás szervezeti fejlődését kivánja bemutatni ezen külső hatásokkal párhuzamosan, két részben.

Az első rész az önálló magyar hírszerzés és elhárítás kialakulásától a II. világháború befejezésig mutatja be ezen szervezetek fejlődését, változásait. A katonai szolgálatok megalakulása, a csendörség és a rendörség politikai rendészeti osztályainak felépítése, vezetői, valamint a társadalmi környezetböl eredő folyamatos átalakulásuk jól tükrözik a kor viszontagságait. A nácizmus térnyerése, majd a Il. világháború eseményei szintén folyamatos változásokat eredményeztek az állambiztonsági közösségben is.

A szervezetek bemutatásán túl érdekes az egyes vezetök további sorsa is, amely információk kevésbé közismertek. Volt, akit kivégeztek, volt, aki külföldre menekült, de volt, aki hátat fordított a szolgálatoknak, és hosszú életkor ért meg egyszerü nyugdijasként.

Kulcsszavak: katonapolitika, hírszerzés, elhárítás, rendőrség, csendőrség, világháború

Intelligence and counterintelligence are integral parts of the current activities of security organisations. Whether it is politics, war, economics, or law enforcement, those who are trying to do it try to learn as much as possible or to keep it a secret. Changes in

Csizner Zoltán r. ezredes, Terrorelhárítási Információs és Bűnügyi Elemző Központ főosztályvezetője; NKE RDI doktorandusz, e-mail: zoltan.csizner@tibek.gov.hu, ORCID: 0000-0002-1867-8560 
political power, social relations, and the surrounding world have a powerful impact on the transformation and work of organisations dedicated to this. The study intends to present the organisational development of domestic intelligence and counterintelligence in parallel with these external influences, in two parts.

The first part presents the development and changes of these organisations from the development of independent Hungarian intelligence and counterintelligence to the end of World War II. The formation of the military services, the structure of the political law enforcement departments of the gendarmerie and the police, their leaders, and their continuous transformation arising from the social environment well reflect the vicissitudes of the age. The rise of Nazism and then the events of World War II also brought about constant changes in the state security community. In addition to the presentation of the organisations, the further fate of each leader is also interesting, which information is less known. There were those who were executed, there were those who fled abroad, but there were those who turned their backs on the services and lived a long life as a simple retiree.

Keywords: military policy, intelligence, counterintelligence, police, gendarmerie, world war

\section{Bevezetés}

Az állam- vagy nemzetbiztonsági szervezetek létrejötte, működése és megszúnése mindig az adott kor történelmi és társadalmi környezetének a ráhatásával zajlott. Így egy olyan tanulmány, amely e szervezetek történelmével foglalkozik, nem nélkülözheti hazánk történelmének a bemutatását sem. Ebbe, az I. világháborútól a kommunista érát lezáró rendszerváltoztatásig tartó, hét évtizedbe két vesztett világháború, egy elbukott forradalom, politikai (mind a jobb-, mind a baloldali) diktatúrák uralma és idegen hatalmak befolyása is beletartozott.

Ilyen változatos körülmények között fejlődött ki és találta szembe magát kihívásaival a magyar hírszerzés és kémelhárítás, amely az 1989-es rendszerváltozást követően, kisebb átalakításokkal ugyan, de egységes és stabil szervezeti struktúrában látja el feladatait napjainkban is.

A szakmai feladatok és kihívások egyaránt megjelentek katonai és belügyi vonalon, amelyek hangsúlyai és arányai mindig az adott kor társadalmi-politikai helyzetétől függtek. Épp ezért ezeket a szervezeteket egymással párhuzamosan, az adott kor történelmének tükrében érdemes vizsgálni.

\section{A korszak történelmi, társadalmi környezete}

Az I. világháború befejezése után, 1918 és 1922 között Európában új önálló államok jöttek létre, köztük a háborúban vesztes oldalon álló Magyarország is. Ebben az időszakban már érezhető volt az a nemzetközi szándék, hogy egy újabb fegyveres konfliktus esetén a vesztes államok ne rendelkezzenek sem támadó fegyverzettel, 
sem azokat alkalmazni képes, nagyobb létszámú hadsereggel. A háborút lezáró békeszerződések, így a Magyarország területi veszteségeit is rögzítő 1920-as trianoni békeszerződés, ezt egyértelművé tették.

E szigorú, és széles körben szélsőséges ellenérzéseket kiváltó korlátok között kellett biztosítani az újonnan visszakapott függetlenség biztonságát, amelyhez a szükséges intézmények, szervezetek hiányoztak. Kézenfekvő volt, hogy a mintát a hosszú évtizedekig létező Osztrák-Magyar Monarchia nyújtsa.

A kezdeti időszakban az 1919-es Magyarországi Tanácsköztársaság, az 1921-ben megalakult Kisantant, ${ }^{2}$ a trianoni békediktátum megszorításai, az 1930-as években a nemzetközi gazdasági válság jellemezte ezt a korszakot, majd a nacionalista ideológia térnyerése, végül a II. világháború kirobbanása, Magyarország hadba lépése, valamint az újbóli vesztesként történő kikerülése. A II. világháború, Magyarország német megszállása és a háborúban vállalt szerepének eltérő megítélése ${ }^{3}$ az időszak utolsó éveiben folyamatos politikai irányváltást ${ }^{4}$ és ennek megfelelő szervezeti és személyi változásokat eredményezett.

A katonai és a polgári hírszerzés, kémelhárítás célszemélyi körébe az időszak kezdetén a Kisantant országainak polgári és katonai hírszerzői, a baloldali eszméket valló személyek, később a zsidók és a náci hatalommal szemben álló - elsősorban baloldali, kommunista - mozgalmak, irányzatok képviselői tartoztak.

\section{Katonai hírszerző szervezetek}

Az őszirózsás forradalom utáni napokban, az újonnan felálló Károlyi-kormány alatt 1918. november 1-jén alakult meg a magyar katonai hírszerzés és kémelhárítás. Az ország újbóli függetlenné válása után sok új állami hivatal a korábbi minta, az Osztrák-Magyar Monarchia intézményrendszerét képezte le. Így volt ez a katonai hírszerzéssel és kémelhárítással is, amely az Evidenzbüro ${ }^{5}$ mintájára épült ki.

A szervezet kialakítása Stojakovics Demeter (1935. november 4-től Sztójay Döme) ${ }^{6}$ nevéhez füződik. A Hadügyminisztérium 1., majd 1919. január 1-jétől 5. osztályaként elsődleges feladata az ellenséges hatalmak által megszállt területekről történő katonai hírszerzés, az onnan irányuló kémtevékenységek megakadályozása, illetve

1921-1938 között erőteljes francia behatás alatt lévő Csehszlovákia, a Szerb-Horvát-Szlovén Királyság és Románia között fennálló katonai és politikai szövetség, amelynek elsődleges célja Magyarország revíziós törekvéseinek megelőzése és visszaszorítása volt.

3 Az 1944 őszén a hatalomra került Lakatos-kormány megpróbált a korábbi kormányzatok által vállaltak ellenére a német birodalomtól elszakadni. A velük szemben álló nyilas-hungarista erők ezt ellenezték, majd az októberi sikertelen kiugrási kísérlet után átvették a hatalmat.

$4 \quad$ All. világháború éveiben zajló politikai események hatásai (Magyarország német megszállása, a Lakatos-kormány sikertelen kiugrási kísérlete, a nyilas-hungaristák hatalomra kerülése, a szövetséges erők bevonulása). A monarchiában a vezérkaron belül múködő Nyilvántartó Iroda, amely magában foglalta a hírszerzést és a kémelhárítást. Utolsó vezetője Maximilia Ronge, akinek feladata volt 1919 júliusában a szervezet felszámolása. Az egyik leghíresebb helyettes vezetője 1908 és 1912 között Ronge egykori kiképzője, Alfred Redl ezredes volt, akit 1913-ban kettős ügynökként lepleztek le.

$6 \quad$ Sztójay Döme (Stojakovics Demeter, 1883-1946), hivatásos katona, majd diplomata. 1944. március 22. és 1944. augusztus 29. között Magyarország miniszterelnöke, és egy ideig külügyminisztere is. A II. világháború után - kormánya több tagjához hasonlóan - halálra ítélték, és 1946. augusztus 22-én kivégezték. 
ezek mellett hadmúveletek tervezése volt.? Stojakovics szakértelmét igazolja, hogy a Magyarországi Tanácsköztársaság idején, Stromfeld Aurél vezérkari ezredes, vezérkari főnök irányítása alatt is ő maradt a katonai hírszerzés és kémelhárítás - kezdetben a Hadügyi Népbiztosság 5. osztálya, majd 1919. május 19-től a Vörös Hadsereg Parancsokság II. csoport - vezetője. ${ }^{8}$

1919. júniustól a szegedi ellenkormány ${ }^{9}$ is felállította saját katonai alakulata, a Nemzeti Hadsereg katonai hírszerző és kémelhárító egységét. Ennek vezetője Ottrubay Károly lett, aki a Magyarországi Tanácsköztársaság bukása és a Friedrich-kormány ${ }^{10}$ augusztusi megalakulása után is a posztján maradt rövid ideig. Ennek a kettősségnek az 1919. novemberi megszűnését követően ismét Stojakovics kezében összpontosult a feladat, és folytatódhatott a szervezet tudatos, célirányos felépítése, amelynek végrehajtását a szakterület vezetőjeként 1925-ig közvetlenül irányította.

Az első években több átszervezésen átesett szervezet életében 1920-ban újabb jelentős változás következett. A trianoni békeszerződés korlátozásai értelmében Magyarország haderejének létszámát 35 ezer főben maximálták, és többek között sem vezérkara, sem vezérkari tisztjei nem lehettek. Emiatt 1920-tól a katonai hírszerzést egy olyan szervezet keretében kellett elrejteni, amelyet az antantellenőrök ${ }^{11}$ nem találtak ellentétesnek a diktátummal.

A vezérkar így a Honvédelmi Minisztérium (HM) VI. csoportjaként működött tovább. Ennek része volt 2. osztály, amely ellátta a hírszerzési és kémelhárítási feladatokat (HM VI-2.). Ez az állapot gyakorlatilag 1938-ig, a nemzetközi megszorítások megszűnését kimondó bledi egyezmény ${ }^{12}$ aláírásig tartott. Az egyezmény elismerte az országok fegyverkezési egyenjogúságát, így Magyarország már teljesjogúan és nyíltan múködtethette a honvéd vezérkart, és ismét 2. vkf. osztály lett az osztály elnevezése.

Stojakovics Demeter vezetése után 1925-től a katonai hírszerzésért és kémelhárításért felelős osztálynak az alábbiak voltak a vezetői:

- Böckl József (1925. szeptember 21. - 1928. október 09.; † Budapest, 1941. március 27.)

- vitéz Ruszkay Jenő (1928. november 15. - 1933. május 1.; † Budapest, 1946. június 22.)

$7 \quad$ Szakály Sándor: A magyar katonai hírszerzés és kémelhárítás szervezetének létrehozása, feladatai és tevékenysége a két világháború közötti Magyarországon (1918-1945). Felderítő Szemle, 17. (2018), 2. 16-37. 17-19. Elérhető: www.knbsz.gov.hu/hu/letoltes/fsz/2018-2.pdf (A letöltés dátuma: 2019. 11. 13.)

$8 \quad$ Szakály Sándor: A 2. vkf. osztály Tanulmányok a magyar katonai hírszerzés és kémelhárítás történetéből 1918-1945. Budapest, Magyar Napló, 2015. 15.

9 1919. május 5 -én bolsevizmus elleni fellépés érdekében gróf Károlyi Gyula vezetésével, francia támogatással Szegeden megalakult ellenkormány, amelynek egyik fő célja volt, hogy „az országban támadt felfordulást megszüntesse". Hadügyminiszterként tagja volt egy ideig Horthy Miklós, aki létrehozta a Nemzeti Hadsereget.

10 1919. augusztus 7-től ideiglenes, majd augusztus 15-től állandó kormány (1919. augusztus 15. - 1919. november 24.), Friedrich István miniszterelnök vezetésével, aki a későbbi Huszár-kormány (1919. november 24. - 2020. március 15.) hadügyminisztere volt.

11 A Szövetségközi Katonai Ellenőrző Bizottság Magyarországra küldött tagjai, akik a Trianonban aláírt diktátum katonai rendelkezéseinek betartását ellenőrizték.

12 A Kisantant és Magyarország között kötött megállapodás, amelyben a Kisantant államai elismerték Magyarország fegyverkezési jogosultságát, aminek fejében hazánk lemondott az elveszített területek erőszakos visszafoglalásáról. Az egyezményt a mai Szlovénia területén lévő Bledben írták alá 1938. augusztus 29-én. 
- vitéz Hennyey Gusztáv (1933. május 1. - 1937. augusztus 1.; † München, 1977. június 14.)

- vitéz dr. Andorka Rezső (1937. augusztus 1. - 1939. május 1.; † Budapest, 1961. március 30.)

- vitéz Ujszászy István (1939. május 1. - 1942. augusztus 1. † ismeretlen, 1948. december után)

- vitéz Vasváry József (1942. augusztus 1. - 1943. augusztus 1.; † Lauterach, 1984. április 24.)

- nemes nyárád-gálfalvi Kádár Gyula (1943. augusztus 1. - 1944. április 17.; † Budapest, 1982. március 14.)

- vitéz Kuthy László (1944. május 4. - 1944. október 16.; † Budapest, 1958. augusztus 30.)

- nemes reszneki Zákó András (1944. október 16. - 1945. május; † München, 1968. március 13. $)^{13}$

A katonai hírszerzés és kémelhárítás fő feladata ebben az időben a Kisantant-államok hírszerző tevékenységének elhárítása, a baloldali (kommunista) törekvések feltárása és elfojtása, valamint - a II. világháború kirobbanása előtt, majd a háború alatt - egyre hangsúlyosabb szerepet kapott a szövetséges hatalmak ${ }^{14}$ elleni hírszerzés és kémelhárítás. Az elhárítás politikai ügyekben szorosan együttmúködött a hazai társszervekkel, azaz a magyar királyi rendőrség Államrendészeti osztályával és a csendőrség Központi Nyomozó Osztályparancsnokságával.

A 2. vkf. osztályon a két nagy szakterület - a katonai hírszerzés és kémelhárítás - mellett további alosztályok működtek, amelyek kiegészítették, támogatták az alaptevékenységet. A két világháború között az alábbi feladatok és alegységek voltak jelen a szervezetben:

- A katonai kémelhárítást az elhárító (defenzív) alosztály (DEF) jelentette, amelyet elkülönítve, a mai Bartók Béla úti ${ }^{15}$ Hadik laktanyában helyeztek el. Az alosztály nem volt büntető hatóság, az általa lefolytatott kémfelderítések anyagát - amelyekben gyakran részt vett a m. kir. rendőrség Államrendészeti osztálya és a csendőrség nyomozóparancsnoksága is - a Honvéd Vezérkar főnökéhez (VKF) rendelt ügyész kapta meg, és ezzel a DEF tevékenysége véget is ért.

- A hírszerzés vezetése és irányítása a központi offenzív alosztály (KOFFA) feladata volt. Ennek során a Honvéd Vezérkar főnöke vagy a hadműveleti csoportfőnök által meghatározott - és a 2. vkf. osztály vezetőjén keresztül érkezett - hírszerzési irányok, célok alapján megtervezték a feladatokat, majd a hírszerző szervezetekkel igyekeztek azokat végrehajtani.

- A nyilvántartó alosztály (NYIL), amely további arcvonalakra (például szovjet, balkán, román, bolgár, angol) osztódott. Itt az egyes országok katonai, politikai és gazdasági helyzetét kísérték figyelemmel és tartották nyilván. Az alosztályhoz 
érkezett be minden felderítési adat a hírszerzőktől, katonai attaséktól vagy más forrásokból (rádióadások figyelése, újságok elemzése stb.). Az alosztálynál napi „Hírnaplót” vezettek az elmúlt 24 órában beérkezett összes hírekről, a forrás megjelölésével és a megbízhatósági fok feltüntetésével.

- A II. világháború időszakára a katonai attaséhivatali rendszer 15-18 állomáshelyet épített ki, ahova legtapasztaltabb és képzettebb vezérkari tiszteket delegálták. A külföldi kirendeltségek közül a bécsi (WEX) és a grazi (GEX) érdemel említést ebben az időszakban.

- Az „X” alosztály, amelynek szakterülete a „rejtmegfejtés” volt, különösen az egyes külföldi követségek és katonai attasék titkosított kommunikációjának a feltörése. A dekódolt anyagokat a HM és a Külügyminisztérium vezetése hasznosította. Az alosztály első vezetője 1920-1925 között a terület elismert szakembere, Pokorny Hermann ${ }^{16}$ volt, aki később más beosztásba került, végül 1935-ben nyugállományba helyezték. Pokorny Hermann, illetve utódai (Kabina Vilmos 1925-1935., Petrikovits István 1935-1945.) által vezetett alosztály előtt a két világháború között kevés megfejtetlen üzenet maradt.

- Idővel megalakult a saját rejtjelező („R”) alosztály is, amelynek feladata a magyar bizalmas közlemények titkosítása volt.

- A rádiófelderítők központja a mátyásföldi katonai repülőtéren volt, míg iránymérők Debrecenben, Kecskeméten, Szegeden és Győrben működtek.

- A lehallgatóállomások, amelyeket Budapest több helyszínén, köztük a Vakok Intézetében alakítottak ki.

- Ezeken túl többek között speciális laboratórium („F”) és nyomda, valamint a személyzeti, pénzügyi, beszerzési ügyekkel foglalkozó alegységek is támogatták a hírszerzők és elhárítók munkáját.

A szakmai feladatokat kellően részletezi az 1930-ban megjelent, két fő részből álló szabályzat. ${ }^{17} \mathrm{~A}$ „Hírszerző Szolgálat 1. rész” a magyar hírszerzés kémkedési ágával foglalkozik, azaz a hírszerzés, nyilvántartás, propaganda, szabotázs és forradalmasítás témaköreit, az alkalmazható személyi, dologi, speciális technikai eszközöket részletezi. A „Hírszerző Szolgálat 2. rész” a kémelhárító szolgálat ellátásáról szóló utasítást tartalmazta. A szabályzat a bevezető részében a hírszerzés feladatát az alábbiak szerint határozta meg: „A hírszerzési szolgálat arra törekszik, hogy megóvja a vezetőséget a meglepetésektől. Ezért állandóan tevékenykedik. Az ellenség katonai helyzetének kifürkészése háborúban felderítők és alakulatok által végrehajtott hírszerzési szolgálat útján történik. A hírszerzési szolgálat egyrészt katonai és katonapolitikai híreket gyűjt,

\footnotetext{
$16 \quad$ Pokorny Hermann (1882-1960), a katonai technikai felderítés, rejtjelfejtés szaktekintélye. Először 1935. május 1-jei hatállyal, altábornagyként helyezték nyugállományba. 1935. augusztustól 1937 márciusáig ismét aktív szolgálatot látott el a rejtmegfejtés területén, majd a Hadilevéltárban fordítói munkát látott el. 1942-ben a Durium hanglemezcég ügyvezető igazgatója lett. Budapest ostroma után jelentkezett a szovjet csapatoknál, és 1949-ben vonult véglegesen nyugállományba vezérezredesként. A láthatatlan hírszerző címmel 1958-ban fejezte be emlékiratait. Pokorny Hermann: Emlékeim - A láthatatlan hírszerző. Budapest, Hadtörténelmi Levéltári Kiadványok, 1999. Elérhető: http://mek.niif.hu/02000/02095/html/ (A letöltés dátuma: 2020. 05. 30.)

$17 \quad$ HM 118.283/eln. VI-2 1930. sz. és HM 119.000./eln. VI-2 1930. sz.
} 
amelyek alapján döntéseit hozza, másrészt lehetetlenné teszi az idegen hírszerzési szolgálat számára, hogy a saját katonai viszonyainkról tájékozódjék."18

A szabályzat mindkét része már az 1930-as években is korszerünek tekinthető alapelveket rögzített, amelyeket később természetesen folyamatosan módosítottak és aktualizáltak. 1942-ben a honvéd vezérkar főnöke újabb szolgálati utasításban"19 szabta meg a 2. vkf. osztály feladatait, amely szerint azokat elsősorban az „idegen államok hadseregének, katonai-politikai viszonyainak és háborús teljesítőképességének nyilvántartása" 20 jelentette.

Az 1944-es nyilas hatalomátvétel után a német birodalom kiszolgálása, a szovjet csapatok elleni hírszerzés és kémelhárítás, majd a szakmai munka mellett a nyugatra történő kitelepítés volt a fő feladat. A szervezet utolsó vezetője, Zákó András 1945 májusában Ausztriában esett fogságba, de végül nem adták ki Magyarországnak. Később Münchenben megalapította a Magyar Harcosok Bajtársi Közösségét, amely 1968-as haláláig az egyik legaktívabb magyarellenes hírszerző és diverzáns szervezet volt.

A katonai hírszerző szervezetek vezetői közül Böckl József nyugdíjazását követően nem sokkal meghalt, Sztójay Dömét és Ruszkay Jenőt a háború után halálra ítélték és kivégezték. Henney Gusztáv - Zákóhoz hasonlóan - nyugatra szökött és Münchenben telepedett le. A többiek rövidebb-hosszabb fogság után civil életet éltek.

\section{Rendőrségi hírszerzés}

A háborút követően a budapesti államrendőrség és a határrendőrség egységes szervezetbe vonásával, 1920-ban megalakult a magyar állami rendőrség, amely a törvényhatósági jogú és rendezett tanácsú városokban - továbbá a belügyminiszter döntése alapján más községekben, községi csoportokban - látta el a rendőrhatósági és rendőrszolgálati feladatokat. ${ }^{21} \mathrm{~A}$ közbiztonságra így a miniszter közvetlen irányítása alatt az 1881-ben létrejött budapesti államrendőrség mellett további 7 új kerületi rendőr-főkapitányság felügyelt, amelyeket főkapitányok vezettek. A 102.837/1922. B. M. számú rendelet ${ }^{22}$ értelmében állami rendőrség felállítására a főváros mellett - ahol két szervezet, a budapesti főkapitányság és a budapestvidéki kerületi főkapitányság is működött - Debrecen, Szeged, Pécs, Szombathely, Székesfehérvár, Miskolc székhelyeken került sor.

Regényi Kund Miklós - Dobák Imre: Hírszerzési és Kémelhárítási Szabályzat a két világháború között. Nemzetbiztonsági Szemle, 3. (2015), 1. (különlenyomat); 146-197. 156. Elérhető: http://epa.oszk.hu/02500/02538/00008/ pdf/EPA02538_nemzetbiztonsagi_szemle_2015_01_146-197.pdf (A letöltés dátuma: 2020. 05. 09.) A Magyar Királyi Honvéd Vezérkar főnökénék 1748.59400 eln. VKF 1942. számú „,Szolgálati Utasítás a m. kir. honvéd vezérkar főnökének helyettese, a vkf. csoportfőnökei, osztályai és egyéb szervei számára”.

Szakály (2015) i. m. (8. lj.) 23-25.

A magyar kormány 1919. évi 5.047. M. E. számú rendelete a rendőrség államosításáról.

A m. kir. belügyminiszternek 102.837/1922. B. M. számú rendelete az 1922:VII. t.-c.-nek a m. kir. állami rendőrségre vonatkozó rendelkezései végrehajtása. 
1921-ben az „összes közbiztonsági szervek élére”23 - beleértve a rendőrfőkapitányságokat, a csendőrséget és a folyami őrséget is - magyar királyi Országos Főkapitányt neveztek ki, amely beosztást 1921. augusztus 7-től Nádosy Imre ${ }^{24}$ töltötte be. Miután azonban a főkapitány belekeveredett a nemzetközi visszhangot is kiváltó frankhamisítási botrányba, ${ }^{25}$ 1926-ban lemondásra kényszerült. Ezt követően a II. világháború végiéig a beosztást nem töltötték be, ${ }^{26}$ a szervezeteket a minisztériumi osztály- és főosztályvezetői szinten irányították.

1922-ben a trianoni békeszerződés következményeként a rendőrség állományát és fegyverzetét is korlátozták, ${ }^{27}$ amely 12 ezer főben maximálta a rendőrség létszámát. A törvény végrehajtási utasítása ${ }^{28}$ alapján a fogalmazói és felügyelői kar 1300 fős, míg az őrségi személyzet létszáma 10700 fő (ebből vidéken 6400 és Budapesten 4300 rendőr) lett.

1924. december 31-ei hatállyal a miskolci és a pécsi, ${ }^{29}$ majd 1932. január 1-jén a megmaradt öt kerületi főkapitányságot is megszüntették. ${ }^{30}$ Ezt követően a megmaradt budapesti rendőr-főkapitányság mellé - a megszüntetett kerületi főkapitányságok helyébe lépő - vidéki rendőr-főkapitányság jött létre, amely szervezeti struktúra a háború végéig megmaradt.

A főkapitányságokon - mind az összevonás előtt, mind azt követően - a bűnügyi osztályok és detektívtestületek teljesítették az általános bűnügyi, nyomozói feladatokat.

A kiemelt búntények nyomozására - beleértve a politikai ügyeket is - 1920 májusában a belügyminisztérium VII. (közbiztonsági) főosztály VII/b. alosztályaként „nyomozó osztály" alakult, amelyet Czövek Sándor főtanácsos vezetett. Az ezt létrehozó rendelet ${ }^{31}$ szerint az egység fő feladata: „Az államrendészeti érdekek hathatósabb védelme, a kémekkel szemben való eredményesebb védekezés, nemkülönben a nagyobb jelentőségú bűnesetek nyomozása”, illetve ezek központi irányítású, egyöntetű végrehajtásának biztosítása.

23 A Horthy Miklós kormányzó és a Ráday Gedeon belügyminiszter által aláírt, 1921. augusztus 7-én kelt kinevezési parancsban szereplő megfogalmazás. A m. királyi Országos Főkapitány kinevezése. Belügyi Közlöny, 26. (1921), 36. 1660.

Nádosy Imre (1872-1935), politikus, előbb Budapest rendőrfőkapitánya (1920-21.), majd országos rendőrfőkapitány (1921-26.) A frankhamisítási botrány miatt 4 év börtönre ítélték, amelyből kedvezménnyel szabadult. 1935-ben influenzában halt meg.

25 1923-tól magyar szélsőjobboldali körök hamis ezer frankos bankjegyek tömeges forgalomba hozatalával próbáltak meg bosszút állni Franciaországon a trianoni békeszerződés miatt. A hamisítás a HM Térképészeti Intézetben zajlott, vélhetően a politikai vezetés tudtával. 1925-ben két futárt fogtak el Amszterdamban több millió névértékű hamis bankjeggyel, akik az akkori rendőrfőkapitány, Nádosy Imre megbízásából és az általa biztosított hamis útlevelekkel szállították azt külföldre. Az ügyben mellettük többek között Windischgrätz Lajos herceget is több évi börtönbüntetésre ítélték.

26 Szikinger István: A magyar rendvédelmi jog 1919-1944. Rendvédelem-történeti Füzetek, 23. (2013), 27-30. 187-197. 193. Elérhető: http://epa.oszk.hu/02100/02176/00013/pdf/EPA02176_rendvedelem_27-30_187-197. pdf (A letöltés dátuma: 2020. 04. 27.) 1922. évi VII. törvénycikkely a magyar királyi állami rendőrség és a magyar királyi csendőrség létszámának, kiegészítési módjainak és felfegyverzésének megállapításáról.

28 A magyar királyi belügyminiszter 102.837.1922. VI/a. száma rendelete az 1922. évi VII. törvénycikknek a magyar királyi állami rendőrségre vonatkozó rendelkezései végrehajtása tárgyában. 246.496/1924. B.M. rendelet kerületi rendőrfőkapitányságok megszüntetéséről és a rendőrhatóságok újabb területi beosztásáról.

30 A m. kir. minisztérium 1931. évi 6.500. M. E. számú rendelete a m. kir. rendőrség szervezeti változásairól.

31 A m. kir. belügyminiszternek 31.300/1920. B. M. számú rendelete a belügyminisztérium kebelében szervezett nyomozó osztály múködéséről. 
Az osztály mind az állami rendőrség, mind pedig a csendőrőrsök nyomozásait jogosult volt magához vonni és azokban feladatokat szabni. Később az osztályt nyomozó hatóságként Központi Nyomozó Hivatallá fejlesztették. ${ }^{32}$ A központosított nyomozóegység 1924-ben megszűnt, ${ }^{33}$ és ezt követően ismét a budapesti és kerületi (később vidéki) rendőr-főkapitányságok feladata lett a bünügyek nyomozása.

1921-től az állami és társadalmi rend felforgatására vagy megsemmisítésére, illetve a magyar állam és a magyar nemzet megbecsülése ellen irányuló bűntetteket és vétségeket már külön törvény ${ }^{34}$ szankcionálta. Ezek nyomozására - először a rendőrségen, majd később a csendőrségen is - önálló szervezeti egységeket hoztak létre.

A belügyminisztérium VII. (közbiztonsági) főosztály VII/a (politikai rendészeti) alosztálya mellett a budapesti és kerületi rendőr-főkapitányságokon már az 1920-as évektől kezdődően működtek politikai nyomozó (fő)csoportok. Ezek közül is a legjelentősebb egység a Budapesti rendőr-főkapitányságon belül kialakított, és az Államrendészeti osztály keretében müködő politikai nyomozó főcsoport volt. Az osztályt a háború, illetve a Magyarországi Tanácsköztársaság után 1921-ben szervezték újjá. Első vezetője Andréka Károly lett, míg a politikai nyomozó főcsoportot dr. Bauer (később Bártfay) Ernő vezette. Miután az Erzsébetvárosi Kör elleni Dohány utcai, halálos áldozatokat is követelő bombamerénylet ${ }^{35}$ nyomozása - állítólagosan Andréka érintettsége miatt - sokáig eredménytelen maradt, 1924 tavaszán az ügyön dolgozó nyomozócsoportot a dr. Hetényi Imre ${ }^{36}$ vezette Útlevél és idegenellenőrző osztályhoz helyezték át. Az itt folytatott nyomozás az elkövetőket felderítette, ami után nem sokkal Andrékát és Bauert más pozícióba helyezték. ${ }^{37}$

1925. január 1-jétől az Államrendészeti osztály élére a korábbi IX. kerületi rendőrkapitányt, dr. Berkes Vilmost nevezték ki. ${ }^{38}$ A mintegy 60 fős politikai nyomozó főcsoport azonban nem maradt az osztályon, hanem dr. Hetényi Imre irányítása alá került, aki azt átalakította és hatékonyabbá tette. ${ }^{39}$ A nyomozói munka mellett

32 A m. kir. belügyminiszternek 9.200/1922. B.M. eln. számú rendelete a belügyminisztérium nyomozó alosztálya elnevezésének megváltoztatásáról.

33 A m. kir. belügyminiszternek 124.037/1924. B.M. számú körrendelete „Központi Nyomozó Hivatal” megszüntetéséről.

34 1921. évi III. tc. az állami és társadalmi rend hatályosabb védelméről.

35 1922. április 3-án pokolgépet robbantottak a Bp. VII. Dohány utca 76. sz. alatti székházban a jobboldali Ébredő Magyarok Egyesületéhez (ÉME) tartozó személyek. A merényletben 8 személy halt meg, és további 23 megsérült. A nyomozás Andréka vezetésével eredménytelen maradt, de később Hetényi irányításával elfogták az elkövetőket, Márffy Józsefet és társait. Az ÉME-hez kötődő és más merényletek miatt szintén elítélt Kovács-testvérek bejáratosak voltak Andréka Károlyhoz. A robbantással részletesebben Kántás Balázs tanulmánya foglalkozik. Kántás Balázs: A bombavetök nyomában - a Horthy-korszak egyik leghírhedtebb büntetőperének politikai kontextusáról és sajtóvisszhangjából. Budapest, Hungarovox, 2020.

36 Dr. Hetényi Imre (1871-1946) orvos, jogász. Búnügyi tudósítóként kezdte pályáját. 1922-től a Budapesti Rendőr-főkapitányság Útlevél és idegenellenőrző osztályának, majd 1932-től a Politikai Nyomozó Osztály, 1933-tól az Államrendészeti Osztály vezetője lett, 1922-től főkapitány-helyettesi címet viselt. 1932-től az 1938-as nyugdíjazásáig az újjászervezett politikai osztályt vezette. Rendőri munkája mellett publikált is, 1941-ben Amikor a rend öre voltam címmel írta meg önéletrajzát. Hetényi Imre: Amikor a rend öre voltam. Budapest, Pantheon, 1941.

37 Varga Krisztián: Az 1945 előtti politikai rendőrség Wayand Tibor detektívfelügyelő önvallomásában. Betekintő, (2009), 1.3-22.8-9. Elérhető: https://betekinto.hu/sites/default/files/betekinto-szamok/teljes_szamok/2009_1.pdf (A letöltés dátuma: 2020. 04. 12.) 
létrehozta az esetleges merényletek megakadályozását célzó helyszínelő csoportokat, lefektette a nyilvántartás alapjait, és a szervezettől eltávolította a szélsőséges politikai eszméket valló detektíveket. A munkarend is a feladathoz igazodott, a hivatali munkaidőn túl ügyeletben és készenléti szolgálatban lévő nyomozók is rendelkezésre álltak a váratlan események, információk kezelésére. Egyforma elszántsággal lépett fel minden radikális jogsértővel szemben, akár a szélsőbaloldalhoz, akár a nemzetiszocialistákhoz tartozott.

Külön említést érdemel a technikai felderítés területe, ahol a telefon- és levélcenzúrákat (ellenőrzéseket, lehallgatásokat) végezték, amelyhez a támogatást a főpostával kialakított együttmúködés jelentette. Az állomány - a monarchiából örökölt szellemiségből eredően - megőrizte polgári tisztviselői jellegét.

A főbb felderítési irányok a kommunisták, illetve kisebb hányadban a betiltott szélsőjobboldali mozgalmak elleni fellépések voltak. A nyomozások többsége Budapesten zajlott, ahol az 1930-as évekre már külön vonalakat (szélsőjobb, szélsőbal, helyszínbiztosítás, vezényelt detektívek felügyelete) is felállítottak. Ebben az időszakban hajtották végre Rákosi Mátyás és Vas Zoltán elfogását (1925), majd az 1931-es biatorbágyi viadukt elleni robbantásos vasúti merényletre ${ }^{40}$ hivatkozással bevezetett statárium keretében több kommunistát is letartóztattak, többek között Fürst Sándort, Sallai Istvánt, Karikás Frigyest vagy Kilián Györgyöt.

1932-ben, a magyar állami rendőrség átszervezése során - amellyel egyben magyar királyi rendőrség lett a szervezet hivatalos elnevezése - a politikai nyomozásokat is központosították. Dr. Hetényi vezetése alatt megalakult a Budapesti Rendőrfőkapitányságon a Politikai rendészeti osztály, amely országos hatáskörrel, egyedüli szervezetként foglalkozott ezt követően a rendőrségen belül a politikai ügyekkel.

1933. január 1-jétől az Államrendészeti osztály is dr. Hetényi irányítása alá került, miután az azt addig vezető dr. Berkes Vilmos a IV. kerületi rendőrkapitányság vezetője lett. Ezt követően dr. Hetényi alá három osztály tartozott, amelyek közvetlen irányítását osztályvezető-helyettesek végezték. A Politikai rendészet budapesti tagozatának irányítója dr. Sombor-Schweinitzer József volt, aki már korábban a politikai nyomozó föcsoportot is vezette.

1938 májusára a Politikai rendészeti osztály a nyilasok elleni fellépései miatt vállalhatatlanná vált a kormány számára, így Hetényit menesztették. Az általa vezetett három osztály élére először dr. Bártfy Ernőt (korábban Bauer Ernő) nevezték ki, akit 1939. februárban a Politikai rendészeti osztály élén Kálnay Gyula váltott. Az ő vezetősége alatt azonban a politikai nyomozásokat lényegében dr. Sombor-Schweinitzer irányította. ${ }^{41} \mathrm{Az}$ osztály érdemi tevékenységének a német megszállás vetett véget, és 1944. március 19-én a Gestapo alakulatai a székházat elfoglalva letartóztatták

40 1931. szeptember 12-én éjszaka Matuska Szilveszter (1882-?) a biatorbágyi viaduktra helyezett pokolgéppel kisiklatta a Bécsbe tartó vonatot, ami a mélybe zuhant. A merényletnek 22 halálos áldozata volt. Matuska más merényletet is elkövetett korábban. Vácon töltött szabadságvesztés-büntetéséből a háború során 1944-ben ismeretlen módon szabadult, további sorsa és halála ismeretlen. A merénylettel részletesebben Vargyai György: A biatorbágyi merénylet címú tanulmánya foglalkozik. Vargyai Gyula: A biatorbágyi merénylet. Budapest, Paktum Nyomdaipari Társaság, 2002. Elérhető: https://mek.oszk.hu/04900/04964/ html/ (A letöltés dátuma: 2020. 04. 10.)

$41 \quad$ Varga i. m. (37. lj.) 12. 
vezetőit. Az így felszámolt osztály állományának jelentős része az 1944-ben megalakult Állambiztonsági Rendészetnél folytatta munkáját.

1945-ben dr. Hetényi Imrét is őrizetbe vették, de egészségi állapota miatt elengedték, majd nem sokkal később, 1946-ban meghalt.

Dr. Sombor-Schweinitzer Józsefet az elfogása után a flossenburgi koncentrációs táborba hurcolták. A szabadulása után 1945-től az amerikai hadseregnél a magyar háborús bűnösök után kutató Himler Márton segítője lett, és csatlakozott az amerikai katonai hírszerzés ${ }^{42}$ kelet-európai ügyekkel foglalkozó központjához, majd 1950-ben az USA-ban telepedett le, és 1953-ban ott halt meg.

\section{A csendőrség}

A csendőrség a háború után kevés változással múködött 1919 tavaszáig, amikor is a Magyarországi Tanácsköztársaság a Vörös Őrség felállításával ${ }^{43}$ megszűntette azt a fővárosi állami rendőrséggel együtt. A Magyarországi Tanácsköztársaság bukását követően a belügyminiszter 1919. augusztus 17-én az első lépései között állította vissza a csendőrséget, amelytől a vidéki közrend stabilizálását várta. A kezdeti létszámgondokat követően - részben a vidéki városi rendőrségek államosításának eredményeként - a szervezet megerősödött, majd ezután már 7 kerületi csendőrparancsnokság és 30 vármegyei csendőrparancsnokság múködött. 1922-ben a trianoni békeszerződés nyomán törvényben ${ }^{44}$ korlátozták a csendőrség létszámát is, és így azt - a rendőrséghez hasonlóan - 12 ezer főben maximálták.

A csendőrség azokon a területeken biztosította közrendet, amelyekre az állami rendőrség illetékessége nem terjedt ki. 1925-ben az ország közel 93 ezer km² területéből mintegy 91 ezer km² tartozott a csendőrséghez, ahol a 8 milliós lakosságból 5,8 millióan éltek. ${ }^{45}$ A két szervezet között rendszeresen előforduló illetékességi összeütközéseket végül a belügyminiszter 1926. évi 74.937. számú, a m. kir. állami rendőrség területén múködő csendőrség viszonyáról a rendőrhatóságokhoz című rendelete oldotta fel.

A csendőrségen belül az első időszakban nem volt önálló nyomozó egység, az illetékességük alá tartozó területen elkövetett büncselekmények nyomozását az érintett csendőrőrs egyenruhás járőre végezte. Ugyan 1920-1924 között a Belügyminisztériumban felállított központi nyomozó osztály a csendőrség nyomozásait is felügyelte és hatáskörbe vonhatta, de ennek megszűnésével visszaállt az eredeti állapot. Az 1920-as évek végére érett meg az igény egy bűncselekményekkel foglalkozó, központosított, jobban felkészített és kiképzett egységre, amelynek tagjai akár civil ruhában is teljesíthették a szolgálatukat. 1928-tól kezdődött meg ennek az új struktúrának a kiépítése, amelynek végeredményeként 1930. március 1-jén

Counter Intelligence Corps (CIC).

A belügyi népbiztos 1. B. N. sz. rendelete a Vörös Őrség felállításáról.

1922. évi VII. tvc. i. m. (27. Ij.)

A m. kir. kormány 1923-1925. évi müködéséről és az ország közállapotairól szóló jelentés és statisztikai évkönyv. Budapest, Athenaeum, 1928. 41. Elérhető: Elérhető: https://adtplus.arcanum.hu/hu/view/KormanyjelentesStatisztikaiEvkonyv_1923-1925/?pg=0\&layout=s (A letöltés dátuma: 2020. 04. 10.) 
belügyminiszteri rendeletet ${ }^{46}$ hirdettek ki. Ez Budapesten egy központi nyomozó osztály és alosztály felállítását, valamint három vidéki városban (Szombathelyen, Szegeden és Debrecenben) egy-egy nyomozó alosztály létrehozását rögzítette. Később ezt tovább bővítették, Így 1931-ben Pécsen, majd 1932-ben Székesfehérváron és Miskolcon is nyomozó alosztályokat hoztak létre. ${ }^{47}$

A csendőrségen belüli központi nyomozóegységek felállításának ötlete Hajnácskőy László - később 1935-től a HM VI-2. DEF alosztály K (kommunista) csoport vezetője, majd 1942. január 1-jétől 1944. október 25-ig a pécsi IV. csendőrkerület parancsnoka, utána a belügyminisztérium államrendészetet is magában foglaló VII. (közbiztonsági) osztályának vezetője - nevéhez füződik, akinek kezdeményezésére jött létre a csendőrség Nyomozó Osztályparancsnoksága. A szervezet első vezetője az 1928-as kezdetektől Tihanyi Ferenc ${ }^{48}$ volt, aki azt 1931-ig irányította.

Az őt követő vezetők:

- dr. vitéz Damasy Farkas (1931. április 1 - 1935. december 15.; † Rakamaz, 1963. január 22.),

- vitéz Sellyey Vilmos (1935. december 15 - 1940. február 1.; † NSZK, 1951. április 14.),

- vitéz Ridegh Raymond (1940. február 1 - 1943. február 1.; † Peru, 1958. szeptember 6.),

- vitéz Czigány József (1943. február 1 - 1944. október 16.; † Vác, 1977. március 16.)

- vitéz Ferenczy László (1944. november? - 1945. május 9. † Budapest, 1946. május 31.) voltak. ${ }^{49}$

A központi nyomozó egységen belül - ami 1942. június 6-tól Magyar Királyi Csendőrség Központi Nyomozó Parancsnoksága lett ${ }^{50}$ - 1931-től egy külön politikai alosztályt is létrehoztak, amely a korabeli belső elhárításként értékelhető. A csendőrség nyomozati munkáját az 1930-ban kiadott „Utasítás a m. kir. csendőrség nyomozó alakulatai számára"51 szabályozta.

A párhuzamosságokból eredően a tevékenységükre rányomta a bélyegét a rendőrséggel való konkurálás, de voltak közös, példaértékűen megszervezett akcióik is.

46 A m. kir. belügyminiszternek 71.464/1930. B. M. számú körrendelete a csendőrségi nyomozó alakulatok felállításáról és csendőr nyomozó utasítás kiadásáról.

47 Rektor Béla: A magyar királyi csendőrség oknyomozó története. Cleveland, Árpád Könyvkiadó Vállalat, 1980. 175. Elérhető: www.rendormuzeum.hu/dokumentumok/Rektor_Bela_Csendorseg.pdf (A letöltés dátuma: 2019. 11. 10.)

48 Tihanyi Ferenc őrnagy (1884-1960), 1905-től a csendőrség tagja, 1920-tól ügyésztiszt, 1924-től a tanulmányi bizottsághoz vezényelve. 1928-tól a csendőrség nyomozó osztályparancsnokság parancsnoka az 1931. április 1-jéig, majd 1931. szeptember 1-jei hatállyal nyugállományba került.

49 Szakály Sándor: Akik a magyar királyi csendőrséget 1919 és 1945 között vezették. Budapest, Magyar Napló, 2014. 19-14., 274.

50 Boda József - Regényi Kund: A hírszerző és biztonsági szolgálatok fejlődése a második világháború végéig. In Boda József - Regényi Kund (szerk.): A hírszerzés története az ókortól napjainkig. Budapest, Dialóg Campus, 2019. 116-129. 124.

51 Parádi József et alii: Nyomozati utasítások a Magyar Királyi Csendőrség számára. Budapest, Szemere BertaIan Magyar Rendvédelem-történeti Tudományos Társaság, 2018. 181-391. Elérhető: http://users.atw.hu/ szbmrtthagyatek/Kiadvanyaink/Nyomozati_utasitasok.pdf (A letöltés dátuma: 2020. 05. 10.) 
Ezek során együttmúködtek mind a rendőrség politikai rendészeti osztályaival, mind a 2. vkf. osztállyal.

Az együttmúködések közül a Politikai rendészeti osztály állományába tartozó Wayand Tibor ${ }^{52}$ 1946. márciusi fogságában írt önvallomásában ${ }^{53}$ részletesen említi az 1940-es alagi nyomozást (amely keretében került sor többek között Kulich Gyula és Schönherz Zoltán elfogására) vagy az 1941. június 29-től szeptember 20-ig tartó észak-erdélyi nyílt nyomozást (amely során 1210 embert vettek őrizetbe, amelyek közül 129 személyt a Honvéd Vezérkar főnökének bírósága hütlenség miatt ítélt el). De hasonló kommunistaellenes nyomozásokra került sor Kárpáralján (1939-1944), a Felvidéken (1939-1944) és Délvidéken (1941-1944), valamint Soroksáron (1943 tavasza és ôsze) is.

A csendőrség vezetői közül a háború után Hajnácskőy Lászlót és Ferency Lászlót halálra ítélték és kivégezték. Ferency -1940-1942 között a kassai VIII. kerületparancsnokság nyomozóalosztályának parancsnoka, majd az 1942. július 10-től a csendőrség Központi Nyomozó Parancsokságának előadója - nyíltan zsidóellenes volt. Az ellene 1946 tavaszán lefolytatott bírósági eljárásban több mint 400 ezer zsidó összegyűjtéséért, gettóba zárásáért és deportálásáért tették felelőssé, amit mint a Magyarországra küldött náci Adolf Eichmannhoz delegált összekötő irányított. Fogsága alatt, 1945 őszén saját kezű feljegyzésben írta le - érezhetően irányított - önvallomását. ${ }^{54}$

A többiek közül Sellyey Vilmos és Ridegh Rajmund külföldre távozott, míg az itthon maradtak kisebb-nagyobb szabadságvesztés-büntetésből szabadultak, illetve szenvedtek el kitelepítést, internálást.

A csendőrséget végül a Nemzeti Ideiglenes Kormány első intézkedései között, ${ }^{55}$ 1945 májusában megszüntette.

\section{6. Államvédelmi Központ, a központi koordináció csúcsszerve}

1942 nyarán egy újfajta, a többi hírszerző szervezet felett álló központi egység létrehozásáról született döntés. Ennek előzménye volt, hogy a belügyi és honvédelmi tárca alá tartozó hírszerző és elhárító szervek (rendőrség, csendőrség és a vezérkari

52 Dr. Wayand Tibor (1880-1949), PRO állományában nyomozó, csoportvezető, majd 1944. október 16-tól az Állambiztonsági Rendészet osztályvezetője, a szervezet 3. embere. A háború után amerikai fogságba került, háborús bűnösként Magyarországnak kiadták, ahol halálra ítélték és - az együttmúködése fejében ígért kegyelmet meghazudtolva - 1949-ben kivégezték. Fogsága alatt 96 oldalas önvallomásban mutatta be a politikai rendőrség munkáját és belső viszonyait.

53 Varga Krisztián: Kommunistaellenes nyomozások a második világháború alatt Wayand Tibor önvallomásában. Betekintő, (2011), 2. 13-51. 15., 37-51. Elérhető: www.betekinto.hu/sites/default/files/betekintoszamok/2011_2_varga_k_0.pdf (A letöltés dátuma: 2019. 11. 10.)

54 Ferenczy László feljegyzései a fogházban 1945. október 30-31. In Molnár Judit: Csendörtiszt a Markóban-Ferenczy László csendőr alezredes a népbíróság előtt. Budapest, Scolar, 2014. 54-62. Elérhető: www. scolar.hu/custom/scolar/image/data/belelapozopdf/Csendortiszt\%20beleolvaso.pdf (A letöltés dátuma: 2020. 05. 02.)

55 Az ideiglenes nemzeti kormány 1945. évi 1.690. M. E. számú rendelete a csendőrség feloszlatásáról és az államrendőrség megszervezéséről. (1945. 05. 07.) 
főnökség egységei) egymással való rivalizálása mind a szakmai munka, mind pedig a konkrét müveletek hatékonyságát nagyban csökkentette. ${ }^{56}$

Mindemellett a megalakulás előtt nem sokkal zajlottak az „újvidéki hideg napok” történései is, amelyek tragikus következményei felvetették az információk pontos értékelésének szükségességét is. 1942 januárjában Délvidéken, egy partizántevékenységre, támadásra utaló, túlértékelt információ alapján indított razzia etnikai alapú tömeggyilkosságba, mészárlásba fordult, amely során a magyar katonai alakulatok mintegy 3300 áldozatot öltek meg. Az 1943 decemberében kezdődött katonai büntetőper 15 vádlottja közül négyen - Feketehalmy-Czeydner Ferenc nyá. altábornagy, Grassy József vezérkari ezredes, Deák László nyá. ezredes és dr. Zöldi Márton cső. százados - 1944. január 15-én Albrecht főherceg segítségével Németországba menekültek, míg a többieket 10-15 év közötti szabadságvesztésre ítélték. ${ }^{57}$

Az 1942. június 26-án kelt rendeletek ${ }^{58}$ alapján július 12-én alakult meg az Államvédelmi Központ (ÁvK), és élére a vezérőrnaggyá előléptetett Ujszászy Istvánt nevezték ki, aki korábban a 2. vkf. osztály vezetője volt, míg helyettese Kudar Lajos csendőr alezredes lett. Az új szervezet a Keresztes-Fischer Ferenc ${ }^{59}$ vezette Belügyminisztériumhoz került, de az irányításban a HM és a vezérkar is szerepet kapott.

Az ÁvK állománya - amely a becslések szerint 30-50 főt jelentett - a rendőrségtől, csendőrségtől és a honvédségtől vezényelt tisztekből állt, majd később oda vezényelt ügyészt is magában foglalt. Feladata a megfigyelések, felderítések és nyomozások irányítása, a feladatok és információk polgári közbiztonsági és katonai szervek között koordinálása volt. Ehhez utasítási jogkörrel rendelkezett, és elméletileg a többi (irányított) szervezett felett helyezkedett el.

A tervek azonban nem teljesültek. Az alárendelt szervek megtartották önállóságukat, és az Ávk-hoz vezényeltek között a belső ellentétek is elhatalmasodtak. Az együttműködés hiányosságait megpróbálták koordinációs értekezletekkel, majd az érintett szervektől összekötők vezénylésével kiküszöbölni, de érdemi hatást ez sem eredményezett. ${ }^{60}$

Az ÁvK így nem tölthette be ténylegesen küldetését, és gyakorlatilag ennek még esélyt sem adva, be is fejezte múködését. Az 1944. március 19-ei német megszállást követően jelentősége erősen csökkent, nem sokkal később Ujszászyt - több más magyar katonai vezetővel együtt - letartóztatták. A szervezetet ezután a volt helyettese, Kudar Lajos vezette tovább. 1944. október 16-tól rövid ideig a 2. vkf. osztály új vezetőjének, Zákó András vezérkari ezredesnek irányítása alá helyezték, majd

$56 \quad$ Kovács Zoltán András: A Janus-arcú tábornok. Adalékok Ujszászy István vezérőrnagy pályaképéhez. In Haraszti György (szerk.): Vallomások a holtak házából-Ujszászy István vezérörnagynak, a 2. vkf. osztály és az Államvédelmi Központ vezetőjének ÁVH fogságban írott feljegyzései. Budapest, Corvina, 2007. 9-72. 49-50.

57 Markó György: Csendőr tisztek a Magyar Királyi Honvéd Vezérkar főnökének bírósága előtt. Rendvédelem-történeti Füzetek, 21. (2011), 24. 73-79. 79. Elérhető: http://epa.niif.hu/02100/02176/00010/pdf/ RTF 24 073-079.pdf (A letöltés dátuma: 2020. 04. 10.)

58 6290/19̄42. Bm.eln. és az azonos tartalmú 52.161/1942. elnöki o. HM Rendelet.

59 Dr. vitéz Keresztes-Fischer Ferenc (1881-1948) ügyvéd, politikus; 1931 és 1935 (a Károlyi Gyula-és a Gömböskormányok), valamint 1938 és 1944 között (az Imrédy-, a második Teleki-, a Bárdossy-és a Kállay-kormányok alatt) belügyminiszter.

60 Kovács Tamás: Államvédelmi központ 1942 - az első kísérlet az egységes magyar állambiztonsági csúcsszerv kialakítására. Pécsi Határőr Tudományos Közlemények, 11. (2010), 339-348. 342-343. Elérhető: www.pecshor.hu/periodika/XI/kovacst.pdf (A letöltés dátuma: 2019. 11. 10.) 
1944. november 15-ei hatállyal végleg megszüntették. Ezután a hatás-és feladatkörét a belügyminisztérium VII. (közbiztonsági) osztály c) (államvédelmi) alosztálya vette át. ${ }^{61}$

Ujszászyt az 1944. április 18-ai letartóztatása után Horthy többszöri kérésére júniusban szabadlábra helyezték, és ellene szoros felügyelet (kórházi ápolás, személyi őrizet laktanyában) mellett folytatták az eljárást. Végül 1944 októberében felmentették a vádak alól, de ezután is bujkálni kényszerült. 1945 februárjában a szovjetek fogták el, és az ott tett vallomásait a nürnbergi perben is felhasználták. 1948 nyarán átadták a magyar államvédelmi szerveknek, ahol az önvallomásait 17 füzetben, Fekete Iván fedőnéven írta le. ${ }^{62}$ Az utolsó írásos feljegyzése 1948 decemberében készült, ezt követő sorsa, halálnak oka és időpontja ismeretlen maradt.

Kudar Lajost a Nemzeti Számonkérő Szervezet 1944. december 4-én elfogta és átadta a németeknek, akik 1945. február 11-én kivégezték.

\section{A nyilas-hungarista kormányzás alatt múködő szervezetek}

Az Állambiztonsági Rendészetet (ÁR) 1944-ben, Magyarország német megszállását követően Jaross Andor, a Sztójay-kormány belügyminisztere, német nyomásra az 1944. március 28-án kiadott rendeletében ${ }^{63}$ hozta létre. A belügyminiszter, illetve az államtitkár ${ }^{64}$ közvetlen irányítása alatt álló, rendőrségen kívüli szervezet vezetésére Hain Pétert, ${ }^{65}$ a Politikai rendészeti osztály egykori detektívfelügyelőjét nevezték ki. ${ }^{66}$ Az ÁR-t, a közismerten szélsőjobboldali szimpatizáns Hain német mintára igyekezett kialakítani, amelynek svábhegyi elhelyezési körlete egybeesett a német titkosszolgálatok budapesti kirendeltségeinek székhelyeivel. A szervezet müködése, felépítése alapján a „magyar Gestapo”-ként vált ismertté. Az új testület személyi állományát gyakorlatilag a német megszállással felszámolt és a rendőr-főkapitányság szervezetéből kiszakított Politikai rendészeti osztály biztosította.

Az ÁR-t - az addig a hazai detektívtestületekben nem alkalmazott - német mintájú struktúra szerint (osztály - alosztály - csoport) alakították ki. Az alkalmazottak kiválasztásánál egyaránt szerepet játszott a szakmai ismeret és a politikai megbízhatóság.

$61 \quad$ Kovács Zoltán András: A Szálasi-kormány belügyminisztériuma-rendvédelem, állambiztonság, közigazgatás a nyilas korszakban. Doktori értekezés. Budapest, 2008. 125. Elérhető: https://idi.btk.pte.hu/dokumentumok/disszertaciok/kovacszoltanandrasphd.pdf (A letöltés dátuma: 2019. 11. 13.)

62 Ujszászy önvallomásai a Haraszti György (szerk.): Vallomások a holtak házából - Ujszászy István vezérörnagynak, a 2. vkf. osztály és az Államvédelmi Központ vezetőjének ÁVH fogságban írott feljegyzései. Corvina, 2007. című kötetben jelentek meg.

63 A belügyminiszter 119/1944. VI. res. rendelete.

64 A rendvédelmi szervek felett diszponáló Baky László belügyi államtitkár.

65 Hain Péter (1984-1946) rendőrfelügyelő, az ÁR vezetője. 1918-tól a budapesti politikai rendészet tagja, 1923-tól a kommunista elleni nyomozócsoport vezetője. 1938-tól Horthy személyi védelméért felelt. 1944ben megalakította az ÁR-t. 1946-ban a Népbíróság halálra ítélte, és 1946. június 27-én kivégezték.

66 Varga Krisztián: Az Állambiztonsági Rendészet és a politikai rendészeti osztály(ok) szervezettörténete 1944. március 28. - 1944. december 25. Betekintő, (2012), 4. 41-66. 43. Elérhető: www. betekinto.hu/sites/default/ files/betekinto-szamok/2012_4_varga_k_0.pdf (A letöltés dátuma: 2020. 04. 12.) 
Az ÁR négy osztályra, illetve ezen belül alosztályokra tagozódott:

I. osztály: a személyügyi igazgatást végezte az ÁR-en belül. Feladata volt ezen túl a szervezeti és múködési szabályzat elkészítése, a jogi normák kialakítása. Az osztály vezetője, Kotsis Árpád, egyben Hain Péter szervezetszerű helyettese is volt.

II. osztály a gazdálkodási és logisztikai feladatokat látta el, amely egyben biztosította a rendőrségtől való függetlenségüket is.

III. osztály állománya kizárólag titkos (operatív) felderítést folytatott, külön célterületként végezte egyes társadalmi alrendszerek (például egyház, tudomány, múvészet, oktatás) bizalmas ellenőrzését.

IV. osztály a kormányzati rendszerrel szemben álló mozgalmak, pártok felderítését végezte, az alábbi alosztályszerkezettel:

IV/1. alosztály: betiltott baloldali pártok, németellenes nemzeti ellenállási mozgalmak;

IV/2. alosztály: kormánnyal szemben álló szélsőjobboldali szervezetek;

IV/3. alosztály: a nem katonai jellegű szabotázsakciók megakadályozása, felderítése;

IV/4. alosztály: faji, biológiai alapú ellenőrzések (zsidóság elleni fellépés, értékszerzés);

IV/5. alosztály: állam- és sajtórendészeti feladatok (amely korábban önálló osztály volt)

IV/6. alosztály: nyilvántartási feladatokat látott el, többek között a külföldiek vagy a rendőrség látókörébe került személyek vonatkozásában.

A fentieken túl az ÁR vezetőjének közvetlen alárendeltségébe speciális feladatokkal megbízott kisebb detektívcsoportok is tartoztak, mint például a készenléti csoport, a helyszínbiztosító csoport vagy a kormányzósági csoport. Utóbbi két egység a kormányzó programjait, illetve rezidenciáját biztosította és védte.

Rövid múködést követően, 1944. június 10-én Hain Pétert elmozdították a vezetői székből, mivel az ÁR tevékenysége és túlkapásai már az őt kinevező politikai vezetésnek sem volt elfogadható. A belügyminiszter Hain felmentését megelőző napon kiadott rendeletével ${ }^{67}$ a minisztérium közbiztonsági főosztályán VII/d. elnevezéssel politikai rendészeti alosztályt létesített, amelynek szervei a rendőrség budapesti főkapitányságának politikai rendészeti osztálya, a rendőrség vidéki főkapitányságának és kapitányságainak erre hivatott szervei, valamint a m. kir. csendőrség központi nyomozó parancsnoksága voltak. A vitéz Ugray Gábor m. kir. csendőralezredes vezetése alá került alosztály feladata „Az ország egész területén a politikai szervezkedések és mozgalmak megfigyelésének, felderítésének és nyomozásának egységes vezetése, irányítása és ellenőrzése." ${ }^{8}$ lett, azaz szakirányítást gyakorolt a politikai rendészettel foglalkozó nyomozóegységek felett.

\footnotetext{
67 A belügyminiszter 1944. június 9-én kelt 4213/1944. eln. számú rendelete. Svéd László: Ságvári Endre mártíriumának körülményei dokumentumok tükrében. Múltunk, (2008), 1. 80-149. 124-126.

68 A belügyminiszter 1944. június 21-én kelt, 11 200/1944. VII. res. számú bizalmas minősítésű rendelete Hain Péter leváltásáról, a rendőrség és csendőrség politikai rendészeti tevékenységének egységesítéséről.
} 
Hain helyére Nagy Valér főtanácsost - aki 1941-ben többek között vitéz Bonczos Miklós későbbi belügyminiszter mellett helyettes kormánybiztosként múködött Délvidéken a csángók hazatelepítésénél, illetve a háború alatt a m. kir. Rendőrség Szaktanulmány Felügyelőségének vezetője volt - nevezték ki. Az új vezető igyekezett eltávolítani Hain bizalmasait, és az ÁR-t a rendőrséggel összhangban múködő szervezetté formálni. Később a miniszteri rendelet ${ }^{69}$ alapján az ÁR átszervezésével a fővárosi rendőr-főkapitányságon Politikai rendészeti osztályt létesített.

A Lakatos Géza vezette kormány sikertelen kiugrási kísérletét követő nyilashungarista hatalomátvételkor, 1944. október 16-án, Hain Péter teátrális módon, géppisztollyal és nyilas karszalaggal bevonulva visszavette az osztály irányítását, és megkezdte az ÁR eredeti szervezeti felépítésének visszaállítását. Töretlen volt azon szándéka, hogy a politikai nyomozásokat a rendőrség irányítása alól kivonja, és ismét függetlenítse az ÁR-t.

A szovjet csapatok előretörése és Budapest kezdődő ostroma után, 1944 decemberének közepétől érdemi tevékenység nem folyt. A fő feladat ebben az időben már a menekülés, a kitelepülés előkészítése volt.

Hain Péter Budapest körülzárása előtt Németországba szökött, ahol elfogták, majd amerikai közremúködéssel kiadták Magyarországnak. Itthon a Népbíróság 1946. május 6-án halálra ítélte, amit 1946. június 27-én végrehajtottak.

Nagy Valért 1946 szeptemberében - miután külföldre szökése után elfogták, majd 1945 októberében többek között Sztójay Dömével és Ruszkay Jenővel együtt az amerikaiak átadták a magyar hatóságoknak - 8 év szabadságvesztésre ítélték.

Nemzeti Számonkérő Különítmény (NSZK): ${ }^{70}$ Az 1944. október 15-16-ai sikertelen kiugrási kísérlet után Szálasi már az első napokban a rendvédelem teljes mértékű átalakításában gondolkozott. November elsején Orendy Norbert ${ }^{71}$ kapta meg az utasítást, hogy hozzon létre egy ideológiailag megbízható, fegyelmezett állományból összeállított különítményt, amelynek fő feladata a rendszer, azaz a hungarista állam ellenségeinek felderítése és letartóztatása, tekintet nélkül arra, hogy civilek vagy katonák. ${ }^{72}$

A szervezet - a belügyminisztérium VII. (közbiztonsági, később közbiztonsági és igazgatási rendészeti) osztály d) alosztályaként - végül az 1944. november 20-án megjelent 30782/res. XX-1944 sz. belügyminiszteri rendelet alapján jött létre Orendy vezetésével, akinek helyettese Komroday Pál, majd 1945. januártól dr. Perlaky Gyula

$69 \quad$ Uo

70 Több forrásban eltérően említik, így szerepel Nemzeti Számonkérés Szervezete, Nemzeti Számonkérő Szervezet vagy csak Számonkérők néven is, de nem keverendő össze a Nemzeti Számonkérő Székkel, ami bírói és vizsgálói testület volt 1944. november 1-jétől.

71 Orendy Norbert (1898-1946) 1921-től csendőr, előbb a székesfehérvári csendőrkerületnél, majd Budapesten és Ungváron szolgált. 1944 májusától a táboricsendőr-nyomozóosztag parancsnoka, majd augusztusától frontszolgálatot teljesített a magyar 2. hadsereg törzsszázadának parancsnokaként, 1944 novemberétől a Nemzeti Számonkérő Különítmény vezetője volt. Kovács Zoltán András: Láday Istvánnak, a Szálasi-kormány belügyminisztériumi államtitkárának fogságban írott feljegyzései. Lymbus, (2008), 321-355. 323.

72 Kovács Zoltán András: A nemzeti számonkérés szervezete - A magyar állambiztonság történetének ismeretlen fejezete. Századok, 136. (2002), 5. 1131-1160. 1133-1134. Elérhető: https://adtplus.arcanum.hu/ hu/view/Szazadok_2002/?pg=1160\&layout=s (A letöltés dátuma: 2020. 09. 29.) 
lett. A megalakuláskor csak néhány osztállyal kezdte meg a működést, és központi székhelye a Bp. I. Naphegy tér 2. szám alatti villaépület lett. Ebben az időben mintegy 20 csendőrtiszt és 250 beosztott alkotta a NSZK-t.73

Az NSZK későbbi pontos létszáma nem ismert, a gazdasági ellátmányok adatai alapján azt 400 fő körülire lehet becsülni.

A NSZK parancsnoki törzse mellett felderítő osztály (Réti Imre vezetésével), nyomozó osztály (Karabélyos Imre), különleges felderítő osztály (Hídvégi István), rohamszázad (Nagy Zsombor) és gazdasági hivatal működött.

A különleges felderítő osztály a korabeli technikai felderítést és hírszerzést folytatta, külön lehallgató csoporttal rendelkezett, amely a rádióadások és telefonok ellenőrzését, illetve helyiséglehallgatásokat végzett titokban. A bizalmatlanságuk odáig vezetett, hogy a magasabb beosztású SS- és SD-parancsnokokat, illetve Szálasi koalíciós társait (Imrédy Béla, Rátz Jenő) is lehallgatták.

Az egység nagyrészt csendőrökből állt, de egyes területekre rendőrök is kerültek. Az eljárásaik nagy része zsidók, katonaszökevények, partizánok, baloldali és kommunista mozgalmak ellen irányultak.

Az NSZK Naphegy téri központja mellett egyes egységei a főváros több pontján (Orvos utca, Tigris utca) voltak. A foglyokat a Margit körúti fegyházban tartották és hallgatták ki. A kihallgatások többsége fizikai bántalmazásból (verésből, villanyozásból) állt, és az eljárások jelentős hányadában halálos ítélet született. Az NSZK fogta el többek között Bajcsy-Zsilinszky Endrét, Kiss János nyugállományú altábornagyot, dr. Tartsay Vilmos nyugállományú századost vagy Nagy Jenő ezredest, akiket még 1944 decemberében ki is végeztek.

Budapest körülzárásakor az NSZK kitelepítése is megkezdődött, de a szervezet egy részének a fővárosban kellett maradnia. A kitelepítés, a Vörös Hadsereg előretörése, Budapest ostroma és felszabadítása ellenére is az utolsó napokig hajtott végre elfogásokat, vallatásokat és kivégzéseket. Az NSZK általi kivégzettek száma - Holecska Tibor vallomása szerint ${ }^{74}$ - a főváros ostroma alatt is meghaladta a 200 főt.

Az NSZK nyugatra távozó egységei 1945. március 29-én Bozsoknál hagyták el Magyarországot, de útközben is könyörtelenül megtorolták a szökési kísérleteket, folyamatosan kutatták a zsidókat és a baloldali szimpatizánsokat. Az elfogottak esetében ekkor már csupán a gyanú is azonos volt a bűnöséggel, és azt, aki gyanúba keveredett, helyben ki is végezték. ${ }^{75}$

Orendy Norbert a német birodalomba távozott, ahol 1945 májusában elfogták, majd kiadták Magyarországnak. A bíróság halálra ítélte, amelyet 1946. június 18-án végre is hajtottak. 


\section{Történelmi áttekintés}

- 1918. november 11. - az I. világháború vége;

- 1919. március 21. és 1919. augusztus 1. között-Magyarországi Tanácsköztársaság;

- 1920. március 1. és 1944. október 16. között - Horthy Miklós kormányzósága;

- 1920. június 4. - békeszerződés aláírása Trianonban

- 1921. június 7. - a „Kisantant” megalakulása;

- 1930-as évek: nemzetközi gazdasági világválság;

- 1932 és 1939 között Gömbös-kormány, majd Darányi- és Imrédy-kormány;

- 1939. szeptember 1. - Lengyelország lerohanása, a Il. világháború kirobbanása;

- 1941. április 3. - 1942. március 9. - Bárdossy-kormány, elkötelezett németbarát;

- 1941. június 26. - Kassa bombázása, utána Magyarország hadba lépése, hadüzenet a Szovjetuniónak;

- 1942. március 9. - 1944. március 22. - Kállay-kormány, németbarát hintapolitika;

- 1944. március 19. - német megszállás;

- 1944. március 22. - 1944. augusztus 29. - Sztójay-kormány, németbarát, antiszemita időszak;

- 1944. augusztus 29. - október 16. - Lakatos-kormány, kiugrási törekvések;

- 1944. szeptember 21. - Magyarország felszabadításának kezdete;

- 1944. október 16. - elbukott kiugrási kísérlet utáni nyilas hatalomátvétel;

- 1944. október 16. - 1945. március 28. - Szálasi-kormány, nyilas-hungarista kormányzat;

- 1944. december 25. és 1945. február 13. között - Budapest ostroma;

- 1944. december 22. és 1945. november 15. között - Dálnoki-kormány, Ideiglenes Nemzeti Kormány;

- 1945 tavasza - nyilas-hungarista kormányzati szervek nyugatra húzódása, kitelepülése;

- 1945. április 4. - a német hadsereg kiúzése Magyarországról.

\section{Felhasznált irodalom}

Boda József - Regényi Kund: A hírszerző és biztonsági szolgálatok fejlődése a második világháború végéig. In Boda József - Regényi Kund (szerk.): A hírszerzés története az ókortól napjainkig. Budapest, Dialóg Campus, 2019. 116-129.

Érdekes áthelyezések a főkapitányságon. Az Est, 1924. 12. 31.

Ferenczy László feljegyzései a fogházban 1945. október 30-31. In Molnár Judit: Csendőrtiszt a Markóban - Ferenczy László csendőr alezredes a népbíróság elött. Budapest, Scolar, 2014. 54-62. Elérhető: www.scolar.hu/custom/scolar/image/data/ belelapozopdf/Csendortiszt\%20beleolvaso.pdf (A letöltés dátuma: 2020. 05. 02.) Hetényi Imre: Amikor a rend öre voltam. Budapest, Pantheon, 1941.

Kántás Balázs: A bombavetök nyomában - a Horthy-korszak egyik leghírhedtebb büntetőperének politikai kontextusáról és sajtóvisszhangjából. Budapest, Hungarovox, 2020. 
Kovács Tamás: A Nemzeti Számonkérő Különítmény. Múltunk, (2006), 3. 71-100. Elérhető: http://epa.oszk.hu/00900/00995/00007/pdf/kovacst.pdf (A letöltés dátuma: 2019. 11. 10.)

Kovács Tamás: Államvédelmi központ 1942 - az első kísérlet az egységes magyar állambiztonsági csúcsszerv kialakítására. Pécsi Határőr Tudományos Közlemények, 11. (2010), 339-348. Elérhető: www.pecshor.hu/periodika/XI/kovacst.pdf (A letöltés dátuma: 2019. 11. 10.)

Kovács Zoltán András: A nemzeti számonkérés szervezete - A magyar állambiztonság történetének ismeretlen fejezete. Századok, 136. (2002), 5. 1131-1160. Elérhető: https://adtplus.arcanum.hu/hu/view/Szazadok_2002/?pg=1160\&layout=s (A letöltés dátuma: 2020. 09. 29.)

Kovács Zoltán András: Láday Istvánnak, a Szálasi-kormány belügyminisztériumi államtitkárának fogságban írott feljegyzései. Lymbus, (2008), 321-355. Elérhető: http://epa.oszk.hu/01500/01500/00006/pdf/13Kovacs.pdf (A letöltés dátuma: 2020. 10. 07.)

Kovács Zoltán András: A Szálasi-kormány belügyminisztériuma-rendvédelem, állambiztonság, közigazgatás a nyilas korszakban. Doktori értekezés. Budapest, 2008. Elérhető: https://idi.btk.pte.hu/dokumentumok/disszertaciok/kovacszoltanandrasphd.pdf (A letöltés dátuma: 2019. 11. 13.)

Kovács Zoltán András: A Janus-arcú tábornok. Adalékok Ujszászy István vezérőrnagy pályaképéhez. In Haraszti György (szerk.): Vallomások a holtak házából - Ujszászy István vezérörnagynak, a 2. vkf. osztály és az Államvédelmi Központ vezetőjének ÁVH fogságban írott feljegyzései. Budapest, Corvina, 2007. 9-72.

Markó György: Csendőr tisztek a Magyar Királyi Honvéd Vezérkar főnökének bírósága előtt. Rendvédelem-történeti Füzetek 21. (2011), 24. 73-79. Elérhető: http:// epa.niif.hu/02100/02176/00010/pdf/RTF_24_073-079.pdf (A letöltés dátuma:)

A m. kir. kormány 1923-1925. évi müködéséröl és az ország közállapotairól szóló jelentés és statisztikai évkönyv. Budapest, Athenaeum, 1928. Elérhető: https:// adtplus.arcanum.hu/hu/view/KormanyjelentesStatisztikaiEvkonyv_1923-1925 /?pg=0\&layout=s (A letöltés dátuma: 2020. 04. 10.)

A m. királyi Országos Főkapitány kinevezése. Belügyi Közlöny, 26. (1921), 36. 1660.

Parádi József -Szakály Sándor - Szigetvári Oszkár - Zétényi Zsolt: Nyomozati utasítások a Magyar Királyi Csendőrség számára. Budapest, Szemere Bertalan Magyar Rendvédelem-történeti Tudományos Társaság, 2018. 181-391. Elérhető: http:// users.atw.hu/szbmrtthagyatek/Kiadvanyaink/Nyomozati_utasitasok.pdf (A letöltés dátuma: 2020. 05. 10.)

Pokorny Hermann: Emlékeim - A láthatatlan hírszerző. Budapest, Hadtörténelmi Levéltári Kiadványok, 1999. Elérhető: http://mek.niif.hu/02000/02095/html/ (A letöltés dátuma: 2020. 05. 30.)

Regényi Kund Miklós - Dobák Imre: Hírszerzési és Kémelhárítási Szabályzat a két világháború között. Nemzetbiztonsági Szemle, 3. (2015), 1. (különlenyomat) 146-197. Elérhető: http://epa.oszk.hu/02500/02538/00008/pdf/EPA02538_nemzetbiztonsagi_szemle_2015_01_146-197.pdf (A letöltés dátuma: 2020.05. 09.) 
CSIZNER ZOLTÁN: A magyar hírszerző és elhárító szervek története 1918-tól...

Rektor Béla: A magyar királyi csendőrség oknyomozó története. Cleveland, Árpád Könyvkiadó Vállalat, 1980. 175. Elérhető: www.rendormuzeum.hu/dokumentumok/Rektor_Bela_Csendorseg.pdf (A letöltés dátuma: 2019. 11. 10.)

Svéd László: Ságvári Endre mártíriumának körülményei dokumentumok tükrében. Múltunk, (2008), 1. 80-149.

Szakály Sándor: A 2. vkf. osztály Tanulmányok a magyar katonai hírszerzés és kémelhárítás történetéből 1918-1945. Budapest, Magyar Napló, 2015.

Szakály Sándor: A magyar katonai hírszerzés és kémelhárítás szervezetének létrehozása, feladatai és tevékenysége a két világháború közötti Magyarországon (1918-1945). Felderítő Szemle, 17. (2018), 2. 16-37. Elérhető: www.knbsz.gov. hu/hu/letoltes/fsz/2018-2.pdf (A letöltés dátuma: 2019. 11. 13.)

Szakály Sándor: Akik a magyar királyi csendörséget 1919 és 1945 között vezették. Budapest, Magyar Napló, 2014.

Szikinger István: A magyar rendvédelmi jog 1919-1944. Rendvédelem-történeti Füzetek, 23. (2013), 27-30. szám, 187-197. Elérhető: http://epa.oszk. hu/02100/02176/00013/pdf/EPA02176_rendvedelem_27-30_187-197.pdf (A letöltés dátuma: 2020. 04. 37.)

Varga Krisztián: Az 1945 előtti politikai rendőrség Wayand Tibor detektívfelügyelő önvallomásában. Betekintő, (2009), 1. 3-22. Elérhető: https://betekinto.hu/sites/ default/files/betekinto-szamok/teljes_szamok/2009_1.pdf (A letöltés dátuma: 2020. 04. 12.)

Varga Krisztián: Az Állambiztonsági Rendészet és a politikai rendészeti osztály(ok) szervezettörténete 1944. március 28. - 1944. december 25. Betekintő, (2012), 4. 41-66. Elérhető: www.betekinto.hu/sites/default/files/betekinto-szamok/2012_4_varga_k_0.pdf (A letöltés dátuma: 2020. 04. 12.)

Varga Krisztián: Kommunistaellenes nyomozások a második világháború alatt Wayand Tibor önvallomásában. Betekintő, (2011), 2. 13-51. Elérhető: www.betekinto.hu/ sites/default/files/betekinto-szamok/2011_2_varga_k_0.pdf (A letöltés dátuma: 2019. 11. 10.)

Vargyai Gyula: A biatorbágyi merénylet. Budapest, Paktum Nyomdaipari Társaság, 2002. Elérhető: https://mek.oszk.hu/04900/04964/html/ (A letöltés dátuma: 2020. 04. 10.)

\section{Jogforrások}

1921. évi III. törvénycikk az állami és társadalmi rend hatályosabb védelméről

1922. évi VII. törvénycikkely a magyar királyi állami rendőrség és a magyar királyi csendőrség létszámának, kiegészítési módjainak és felfegyverzésének megállapításáról 5.047/1919. M.E. rendelet a rendőrség államosításáról

6.500/1931. M.E. rendelet a m. kir. rendőrség szervezeti változásairól

1.690/1945. M.E. rendelet a csendőrség feloszlatásáról és az államrendőrség megszervezéséről

B. N. sz. rendelet a Vörös Őrség felállításáról 
31.300/1920. B.M. rendelet a belügyminisztérium kebelében szervezett nyomozó osztály múködéséről

102.837/1922. B.M. rendelet az 1922. VII. tc-nek a m. kir. állami rendőrségre vonatkozó rendelkezéseinek végrehajtása

9.200/1922. B.M. eln. rendelet a belügyminisztérium nyomozó alosztálya elnevezésének megváltoztatásáról

124.037/1924. B.M. számú körrendelet a Központi Nyomozó Hivatal megszüntetéséről 246.496/1924. B.M. rendelet kerületi rendőrfőkapitányságok megszüntetéséről, és a rendőrhatóságok újabb területi beosztásáról

74.937/1926. B.M. körrendelet a m. kir. állami rendőrség területén múködő csendőrség viszonyáról a rendőrhatóságokhoz

71.464/1930. B.M. körrendelete a csendőrségi nyomozó alakulatok felállásáról és csendőr nyomozó utasítás kiadásáról

11.200/1944. B.M. VII. res. rendelet Hain Péter leváltásáról, a rendőrség és csendőrség politikai rendészeti tevékenységének egységesítéséről

118.283/eln. VI-2 1930. sz. és 119.000./eln. VI-2 1930. sz. HM utasítás

1748.59400 eln. VKF 1942. számú Szolgálati Utasítás a m. kir. honvéd vezérkar főnökének helyettese, a vkf. csoportfőnökei, osztályai és egyéb szervei számára 